\title{
Mapping their Road to University: First-Generation Students' Choice and Decision of University
}

\author{
Faridah Mydin Kutty ${ }^{1}$ \\ ${ }^{1}$ Faculty of Education, Universiti Kebangsaan Malaysia, Malaysia \\ Correspondence: Faridah Mydin Kutty, Faculty of Education, Universiti Kebangsaan Malaysia, 43600 UKM \\ Bangi, Selangor, Malaysia. Tel: 603-8921-7695.E-mail: faridah_mydin@ukm.my
}

Received: July 22, 2014 Accepted: November 5, 2014 Online Published: December 21, 2014

doi:10.5539/ies.v7n13p49 URL: http://dx.doi.org/10.5539/ies.v7n13p49

\begin{abstract}
This paper describes a qualitative case study that investigated the aspirations and decision-making process of first-generation students concerning university education. The participants comprised of 16 first-generation students at a research university. Data were obtained through interviews and analyzed using thematic analysis method. The analyses centered on extracting meaning from factors behind students' university decisions. The student accounts highlight five factors in the process of negotiating their decision to enter the university: personal motivation i.e. individual perceptions of their intellectual ability to meet their expectation of entering university; family-based motivation particularly the parents' socio-economic status and involvement in students education; the role played by siblings and extended family; characteristics and context of the school attended; social networks as a medium where the information of university was transferred. The paper suggests that students' decisions on university education are contextualized as part of a web of complex interactions. Decisions about university education involved interaction between an individual's agency and strong influences of third parties which provide suggestions for the school and higher education institutions to consider the best medium by which they can help to increase students' awareness of university education.
\end{abstract}

Keywords: Malaysia, university, access, participation, first-generation students, working-class, motivation

\section{Introduction}

First-generation student represent a population of students first is their families to attend university, or with parents who have not obtained any post-secondary qualifications (Inkelas et al., 2007; Jehangir, 2010; Thomas \& Quinn, 2006). In Malaysia the concept of first-generation is not well developed in higher education literature or in any other studies. In a study by Abdul-Rahim and Azman (2010) on first-generation students' educational aspirations, this definition is used. Accordingly, in this article the first-generation student refer to those from a family with no post-secondary qualification and from working-class backgrounds. That the definition based on parents' education level is important, because even though some first-generation parents have no higher education qualifications, they may have high financial capital and could provide their children with resources that would increase their social and cultural capital.

This article tentatively offers a contribution for first-generation students on 'what motivate' for students with no family history of higher education. Personal accounts describe how students have faced challenges in their academic pathways, the motivations behind their decisions and actions, and factors behind their success and failures. Through an examination of how the students viewed the contextual features of their family backgrounds, schooling experience and structural factors as influencing their process of deciding to go to university. The findings of this research will offer new perspectives into continuing discussion on first-generation student from a Malaysian perspective. This indirectly answers the question of whether there is a relationship between students' social class and higher education aspiration and choices.

There is a much debate regarding the factors that might shape students' post-secondary expectations and choices. Post-school choices are seen as a multifaceted process, differing by social class, gender, age, ethnicity, family backgrounds and parent's education. In a study of factors that shape young people's decisions on higher education, Smyth and Banks (2012) conclude that the decision reflects: individual habitus; the institutional habitus of the school identified from the available resources and guidance provided; and finally people's own agency, individual ability to access information on different options and make their own judgement. In this 
section, three main domains of personal attributes, family social and cultural capital, and schooling experience are selected to discuss the extent it affects student higher education aspirations.

Individual personal attributes relates with student academic self-concept, aspiration and academic achievement that contribute to their future outcomes, particularly their educational and occupational attainment. For example studies by Beal and Crockett (2010); King et al. (2006); Little (2007); Nurmi (2004) and Troutman and Dufur (2007) all explain 'future oriented cognitions' motivate behaviour related to the realisation of preferred outcomes. When students have clear goals they are able to think about their educational paths to help them achieve their occupational goals. Schneider and Stevenson (1999) label it as an 'aligned ambition' a match between educational aspirations and occupational ambitions. The link between expectation and later attainment is agreed by Messersmith and Schulenberg (2008) and Ou and Reynolds (2008) state that adolescents' educational expectations predict their educational attainment. Students' motivation for post-secondary education can be as either an intrinsic or extrinsic factor. Findings by Cote and Levine (1997) suggest that student motivations for attending university are based on five motivations: the careerist-materialist motivation; personal-intellectual development; humanitarian motivation; expectation-driven motivation and default motivation. The external motivation implies performing behaviour that fulfils other people's ambitions or to gain some other external reward. It is also known as collectivist motivation, when students go to university to meet the expectations of the family.

Children's educational aspirations and attainment are indirectly related to parents' educational expectations (Benner \& Mistry, 2007; Marjoribanks, 2005; Mistry et al., 2009; Kirk et al., 2011). Conversely, their child's academic achievement may influence parents' educational expectations for their children (Goldenberg et al., 2001). For working-class students, attending university and getting a degree is seen as a plausible way of increasing their job prospects and future income (Archer and Hutchings, 2000). It enables them to develop 'personal capital' along with those from middle-class educated backgrounds (Blackstone, 2001; Forsyth \& Furlong, 2003).

According to Lareau (2003) and Bodovski (2010), parents' educational and occupational level is positively associated with the educational attainment of their children. Parental socio-economic status is conventionally measured by educational and occupational status. As a counter to this, Saunders (2002) concludes that 'able parents will be more likely to produce relatively able children (because of the genetic and environmental advantages that they can pass on), and these children will often, therefore, emulate the achievements of their parents' (pp. 560-561). Furthermore, a child whose parents experienced higher education normally grows up with access to more college-related cultural capital and knowledge about university, and has clearer and more systematic educational plans (Ball et al., 2002; Greenbank, 2007; Laming, 2010; Sianou-Kyrgiou \& Tsiplakides, 2011). In this regard, parental influences has been cited as 'one of the best predictors of post-secondary educational aspirations' (McCarron \& Inkelas, 2006, p. 536), in particular, parental experience of higher education (Reay et al., 2001). Lack of the kind of cultural capital possessed by upper- and middle-class families are among the most well-known reasons that students' from poorer backgrounds are so much less likely to participate in higher education (Archer et al., 2003; Gibbons \& Vignoles, 2009; McMillan \& Western, 2000). What is more important for working-class parents is providing basic necessities such as clothing, food and housing (Lareau, 2000). Although they may want their children to pursue higher education, their influence could be considered weaker because they have limited financial and social resources, and a lack of first-hand knowledge of higher education (concerning the teaching quality or the rank of the university) that limits their capacity to facilitate higher education planning (Ceja, 2006; Oliverez \& Tierney, 2005; Pugsley \& Coffey, 2002; Thayer, 2000).

In evaluating the relationship between parents' educational and occupational level with the educational attainment of their children, this field has had a tendency to over-emphasize the disadvantage of student with low cultural capital when competing with the academic structure and to de-emphasize other aspects of social reality. There has been less work on how factors like parental beliefs such as achievement expectations or efficacy might function as links between socio-economic status (SES) and achievement outcomes. For instance, parental encouragement, expectation and involvement in the child's education can compensate for disadvantages associated with social class background (Kirk et al., 2011; Saenz et al., 2007). Hossler, Schmit, and Vesper (1999, p. 24) see parental encouragement as 'the frequency of discussions between parents and students about parents' expectations, hopes, and dreams for their children'. According to Simon, Murphy, and Smith (2005), determination to overcome their difficulties makes them feel strengthened and more confident. Thus, children of poor but resilient families are capable of accomplishing both academic and social-psychological achievements despite the lack of economic resources in their homes (Orthner et al., 2004). This is supported by the finding of 
McCarron and Inkelas (2006) of a positive relationship between parental involvement and educational aspirations of first-generation students. Parent-child communication, as a form of home-based involvement, is beneficial to children's success if the communication focuses on school matters (Epstein \& Sheldon, 2006).

Certain knowledge and behaviours valued and rewarded in educational institutions are inherited from the family and its social structures. However such values do not exist in every family, so individuals have had to obtain from other resources, for example school. As noted by Benbenishty and Astor (2005), school is at the centre of a child's ecological system and is perceived to be the most influential of the social context as a predictor of their development. Early studies by Becker (1962) have proven educational institutions cultivate human capital in terms of skills, knowledge, and strategies that boost individual productivity. Educational research has demonstrated that positive schooling environments a powerful contextual factor that can bridge the disadvantage faced by a certain group of students by offering access to educational, social and cultural capital (Harris et al., 2002; Morgan \& Sorenson, 1999; Younger \& Warrington, 2009). This developed from the interaction of student and teacher and among pupils in school.

To illustrate the connection between school and university education, Engberg and Wolniak (2009) note the importance of activities at high school in facilitating student to enter college. High school is where a student is exposed to early expectations about the tacit knowledge required at university level. As stated by Conley (2008), 'the likelihood that students will make a successful transition to the college environment is often a function of their readiness - the degree to which previous educational and personal experiences have equipped them for the expectations and demands they will encounter in college' (p. 24). According to Conley, the key to making a successful transition is 'student readiness' and this is organized around four key components: key cognitive; key content; academic behaviours; and contextual skills and awareness. Concept readiness, invariably more than the qualifications students use to achieve entry to university or their course, and also the skills and the knowledge and personal competence are major contributions to adjusting to the new environment (Cline et al., 2007; Wyer, 2005).

Apart from its main function in delivering curriculum, school is a social organization that provides opportunities for social interaction. Additionally, peers are another set of factors with direct impact on higher education aspirations among school students. The environment of the classroom with other students intent on pursuing their studies to higher education increases the likelihood that they, too, will aspire to attend university (Tierney and Colyar, 2005). Discussion with peers about educational and career aspirations stimulates and increases university-going behaviours among students. Extra-curricular activities such as academic clubs, sports, performance arts and language are other factors positively affecting student achievement (Grolnick et al., 2007; Shulruf et al., 2008). A range of activities offered by a school not only increases student involvement but establishes social networks between peers and increases the student competence level.

This article focuses on the transition experiences of a small group of first-generation students who moved from sixth-form to the undergraduate programme at University Kebangsaan Malaysia (UKM). A fundamental concern is to understand the relationship between student socio-economic status and higher education choices and decisions.

\section{Method}

This study took place at a medium-sized research university in the west of Malaysia. This study is designed as a qualitative study. The exploration offers opportunities for the researcher to understand and discover issues that are rarely discussed through the voices of the participants. As stated by Roe (2005), qualitative research into the nature of students' transitions to university offers valuable insights into the internal and external contexts and factors that can influence the process. A total of 16 undergraduate first-generations students from Universiti Kebangsaan Malaysia (UKM) participated in this study. Semi structured, in-depth interviews were used. Interview data was transcribed and analysed using an interpretative thematic approach.

\section{Results}

In this section, the factors that motivate student to enter the university will be analysed. Several different meanings or interpretations are attached to how students think about studying at university. The analyses suggest that the whole objective aiming for and entering university is desire for self-improvement: educationally, financially, and professionally. Students' perspectives of university education and their decision to enter the university were influenced by various factors. In other words, decisions on university education are not solely an outcome of individual academic potential and achievement, but relate to the impact of surroundings factors with which their behaviour interacts to influence each other. 


\subsection{Self-Motivation}

The most obvious and consistent theme that emerges from the interviews with students who participated in this study was the majority of them wanted 'to be the best' and they wanted to become a successful person and that they believed it could be achieved by going to university. Three key goals were identified that underpinned their decision to further their education to university: academic goals, career aspirations and personal development.

\subsubsection{Academic Goal}

Attitudes towards higher education or knowledge about higher education developed when student progressed to secondary school. Transition to secondary school, especially upper secondary, is a highly significant move for all students. Thus the SPM (Malaysia Certificate of Education) or equivalent to GCSE (General Certificate of Secondary Education) result operates as internal guiding system for students to plan the next stage of their education journey. For student who failed to get high grades, sixth-form had served as an alternative pathway for university entrance. For this student the opportunity to enter sixth-form was perceived as a second chance for them to improve on their previous performance. For example, for Avin his decision to put his best effort and worked consistently and reasonably hard at sixth-form, not only to overcome his past experience of failure, but not to disappointment his parents hope. Overall, students enter sixth form with the motivation to overcome weaknesses and to perform well in examinations as preparations for university education. The importance of achieving high grades in national university entrance examination was important, especially when participation in public higher education in Malaysia has always been very competitive.

Based on the findings, individual student behaviour, actions, thoughts and beliefs are influenced by their inner drive to succeed. It is not surprising that the issue of earning high grades is pressing. Within this context, high school grades are often viewed as representations towards a specific end. As for example from what Nissa mentioned:

You have to suffer and struggle, because everyone have potential to enter university...everyone fight for the place...however the advantage only for those with high pointer..so you need to get high pointer (Nissa, Interview)

In this analysis, the overall understanding of the students presented here is about strong self-determination to increase their academic performance to achieve their goal. Student's believed 'hard work' as a key value to achieve a certain goal, especially when individuals from different socio-economic and educational backgrounds and academic ability compete for same objective. High academic motivation is an important attitude presented by the students, who are optimistic about the actions needed to be taken to help them to secure brighter future. The importance of getting high grades in not limited to meeting the entry requirements for university, but to be admitted to the university and course in which they were interested and finally to qualify for a scholarship.

\subsubsection{Career Aspiration}

Student motivation to perform academically is supported by their clear career goals. Students consistently mentioned that higher education credentials were perceived as essential aspects within the context of a credential-inflated labour market. In this study, eight students exhibit a positive and proactive approach to their academic pathways when they have well-articulated ambitions and plans. According to Schneider and Stenvenson (1999, p. 6), 'students with aligned ambitions knows the type of job they want and how much education is needed to get it'. Two students described their reason to choose Law, fulfilling their parents' ambition, idealistic interest in law subject. From a different position the reason Nissa's choose Law was the 'status' the course brought in what is apparently an elite subject within arts. She clearly stated that selecting this kind of course would automatically increase her status in society: as she said:

Better position and high status in society (Nissa, interview)

She believed that she was honoured as a first-generation student from a working-class background to enter a programme dominated by students from high and middle-class backgrounds. Furthermore, four students' explained they decided to apply for teaching, was driven by their temporary teaching experience after sixth-form and while waiting for their results. In another example one student explained the reason he chooses Teaching in Sports course because of his talent in sports and experience in teaching.

The students' statements demonstrated that, apart from individual targets, surrounding factors have a great impact on student career decisions, ranging from parents' expectations, a desire to increase social status, family role models, working experience and a desire to explore new opportunities. The limitation surrounds them, especially their class origin, is not a constraint for these students in their aim for a professional occupation. Future career goals and aspiration as a way to stay focused, and they used these goals to fuel their internal 
motivation.

\subsubsection{Personal Development}

Student expressed a strong belief that university education is an opportunity for self-improvement. In particular student highlighted four main skills they intended to develop: leadership skills, self-confidence, self-independence and communication skills. Students express the idea that university is a way of 'bettering oneself'. Students' remarks on the personal beliefs of higher education reflect a view that university education is an opportunity for self-discovery and self-improvement.

\subsection{Family-Based Motivation}

The family factor identified in this research look at the role played by parents, siblings and extended family. The ways which parents contribute to students' higher education aspirations has three aspects.

\subsubsection{Parents' Socio-Economic Status}

The first that arose from the data relates to parents' low socio-economic status which is invariably associated with: low educational level, low occupational status, and low level of income. The reality faced by these students makes them more responsive to their obligation to support their family in future. The obligation to support family becomes more pressing especially for the eldest child or the child of single parents. For example as mentioned by Avin:

I am the eldest in the family, and I am responsible to look after my parents in future (Avin, Interview)

The pressure to support family more intense for those brought up by single parents like Tino and Gary. Tino witnessed the struggles and obstacles his mother underwent to raise him and his brother due to her status as a single mother. For these students the value of academic success in not only associated with a sense of duty to support family but indirectly increases their parents' status in society. In the cultural context of society, especially in working-class families success in education is highly valued.

\subsubsection{Parents' Expectation}

The findings show that parental expectation has a significant impact on student personal motivation. Parents' expectations for their child's educational attainment and future career act as pushing factor for students to perform better in academics and motivate them to enter university. As Milly said:

My father always expected me to go to university (Milly, Interview)

Some parents show level of job expectations, and six students mentioned that their parents have occupational expectations of them. According to these students, this is based on aspects such as security, income and status. In Harn's case for example, her parents wanted her to become a teacher because they felt it was more secure in terms of a job, while for Avin, Mirul, and Prema, Law was chosen to respect their parents' wishes for a career that is valued and respected in society.

\subsubsection{Parents' Support}

Parent's encouragement supports students' educational process. Even though parents in this study were not directly involved with their child's university preparation and planning, but students are strongly encouraged by their parents through: advice, informal family communication, a positive learning environment at home, and a provisional of additional resources for study (e.g: extra tuition and book purchases). Findings from this study give insights into the importance of advice on a child's psychological well-being. For example, according to Avin, without the support and belief from his parents he would not have achieved high pointer in his public examination, as he said:

...with the support, believed and trust they give on me, I manage to makes this dream come true...(Avin, Interview)

Some parents involved directly with their child university education plan, for example Ying's mother gather information about universities, courses, and scholarships from the teachers at her workplace by asking what they have planned for their children and what is the best she can do for her child. This is exceptional case, when only one student mentioned this.

\subsubsection{Siblings}

For students, having siblings go on to higher education or still studying gives them an advantage in terms of providing them with knowledge about what to expect from university, and information about courses and which university to attend. In this research, five students referred to being partly motivated by their older brother or 
sister studying or graduating from university. According to Shah (2007), in a working-class family the older siblings generate cultural capitals for the family. For example, Harn's decision to enter UKM was directly influenced by her elder sister, and for her having a sister at the same university provided emotional support, especially in the early socialisation process:

My sister influenced my decision to go into UKM, because easy I have someone to guide me (Harn, Interview)

At the same time, the analysis also reveals new themes not widely discussed in the fields of sibling influence. For example, older siblings' success in non-academic fields (business) is seen as motivation to succeed on the field in which they think they have more strength. In different circumstances, elder siblings' position of lower success in academic studies or sacrifices to be made to support the family indirectly contributes to students' aspiration for a degree. The same concerned also described by 11 participants as the first child in the family to attend university, they hope their achievement in entering university would have positive impact on the decision of younger siblings to study at university.

\subsubsection{Social Environment}

This study support emphasised the importance of social networks in the context of intergenerational relationship such as relatives, friends and extra-familial adults (Shah et al., 2011). A child interact with people surround them, this social environment would stimulate students' intellectual engagement and cognitive growth. High occupational success and advanced degrees awarded to family members or others could be perceived as a motivation for parents to encourage their children into higher education, or the child to take it as self-motivation. This accord with a study by Ituma and Simpson (2006), the influence of extended family on the educational and career aspirations of Nigerian's youths. Extended family in this study focuses on the potential impact of other family members such as uncles, aunts and cousin. Seven of the students reported that their relatives studying at university, or who had graduated and had a successful career, formed important social networks and act as a role model and provide information about the university. The extended family members acted as what Crozier and Davies (2006, p. 685) describe as "high-status role models". Cross-ethnic networks (Shah et al., 2010) through family networks had allowed them to acquire some degree of dominant cultural capital. For example, Emma's develops her interest to become an English lecturer through her aunt who is an English lecturer. Normally they used them as a resource for information about university or the course or as a role model. For first-generation students, the social networks that develop with relatives enable them to share information and resources about university and help navigate the pathway to university.

\subsection{The School Habitus}

The way schools prepare their students may also have a significant effect on pathways to higher education. Students described the school culture, classroom-level factors, and involvements in school activities cultivate their skills, knowledge that boosts individual productivity.

\subsubsection{Positive Learning Experience}

Students are more motivated to do well and achieve their full potential in schools that have a positive school cultures. For example, Tino's schooling was in a school located in a major city with a good academic reputation and a high number of students progressed to university. Good resources and facilities helped him to develop his academic potential and socio-cultural capital. Tino performed well academically and mixed well within the community: he was chosen as head boy and a class monitor when he was in sixth-form, actively participated in clubs and games. Without being judged or being seen as different, Tino mixed well and was sociable with teacher and peers.

Students also described educational system practices at school that indirectly affect their academic attitudes. This is share by Ting and Ying from Chinese school emphasis on the importance of knowledge, competitiveness and achievement. Thus, not surprisingly, both these students mentioned that they always aimed for good grades. A part from what is emphasised by the school in general, the transition to sixth-form is an important turning point for a number of students. Transition to sixth-form is transition from traditional learning to independent and self-motivated study. Thus, not surprisingly, some students perceived their learning experience in sixth-form is to be an important or interesting period of schooling different from their previous academic experience. For example, as noted in Azif's extract

I am more excited with my study in sixth from, the academic practices different (Azif, Interview)

School helps to increase student awareness on university education also through school activities: a university visiting programme and seminar and talks by a former student. This was identified as an excellent opportunity for students to developed early expectations of a university education. For example, five students said a 
university visit was a reasonably strong influence on their early aspiration for university and in particular on their preference for a particular institution and field of study.

\subsubsection{The Role of Teachers}

Teacher at school seem to hold a pre-eminent position in students' early conceptions and expectations of university. Teachers are perceived as important agents for a working-class student in several ways: motivation and academic support, and knowledge about university. One student noted with regard to her teacher:

besides my parents, the second motivation for me to enter university is my teacher (Milly, Interview)

While for Nissa her teacher's expectations and belief in her academic ability affected her achievement motivation:

...the teacher always support me, they always motivate me and tell me that I would enter the university...so their expectation give me big inspiration (Nissa, Interview)

This is supported by views from Stewart (2006) and Benner and Mistry (2007), where teacher's expectation affects students' academic success. Furthermore, students in this study rely heavily on teachers for university information. According to the students, their teacher or counsellor is their main reference for university education, ranging from help with university and course selection, to sharing their experiences of university education. Almost all students contacted their teacher or counsellor to get advice about their decision on which course to choose, entrance qualifications, selection process and career prospects. Students consult teacher because they perceive them as more experienced and with more knowledge, and thus able to assist them with the selection process. In this context, to some extent teachers play an important role in advising on what they think is best for students based on their knowledge. Potentially a teacher at school should prepare students with some level of relevant knowledge about the course and the university, because for working-class students with low access to this kind of knowledge at home, they represent the preferred source of information and so it a matter for concern that they give transparent information on all aspects of the university.

\subsubsection{The Role of Peers}

Furthermore, some students sought guidance from peers at school or older friends who had successfully continued their post-secondary trajectory. In this context, Gibson et al. (2004) posit that peers can be ideal sources of university college knowledge and social capital through social networks and value orientation. At sixth-form, every student comes with the same aspiration to enter university, as Abby said:

...every one of us in same level, and everyone have one target to enter the university (Abby, Interview)

Being within a group of student with the same goals is the best opportunity for students from different socio-economic backgrounds to share information and preferences for universities. Through this process information provided can lead to be more informed and better choices. Another medium for information is students' seniors, whether from same school or tuition centre, studying their particular course at their particular university. These experiential sources, as described by Dyke et al. (2008), are based on their personal experiences at the institution by "word-of-mouth" (James et al., 1999). The information from their senior helps them learn about the course in terms of the admission process, course structure, learning process, medium of instruction, exams, and the lecturer. For Nissa, Avin, Tino and Prema without direct access from their home environment, a senior's experience at university helped to build some early expectations about university education. For example, as commented by Prema:

...my senior which studying at UKM give me some information about the course, like the language used, the assignment, the language used...so I came here with some information even though not in very details (Prema, Interview)

A number of points emerged, suggesting that the schools structure and practices make differences to students' educational and personal development.

\section{Discussion}

Addressing the research objective on students' motivation to attend university, analysis of interviews found that their intention is a multiple intersection between personal motivation and socio-cultural factors. As described by Sianou-Kyrgiou and Tsiplakides (2011) higher education choice is a multifaceted process. This indirectly answers the question of whether there is a relationship between students' social class and higher education aspiration and choices.

Student desire to enter university had developed at early schooling years and normally supported by student 
academic ability. Thus this supports Marjoribanks (2003) idea that student academic performance at the beginning of secondary school has an impact on the formation of adolescents' educational aspirations. Whether it developed from the beginning or came later, students stated they saw university as a next step in their educational pathways. The degree to which they are committed to attend university was influenced by their academic, career, and personal development goals. Degree aspirations often lead to academic preparation, and the researcher has found that strong academic preparation plays a major role in student's path to university regardless of socio-economic status (Cabrera et al., 2003). Growing awareness of their own abilities, personal preferences and opportunities available to them based on performance in exams, have more realistic expectations. The motivations embraced are beliefs that individuals have the chance to be educated to any level, based on their performance and achievement. Archer et al. (2003) an emphasis on qualifications and credentials clearly reflects dominant conceptions of achieving social mobility. Therefore failing to achieve high grades or not succeed would be 'immoral' as they realise their parents have fewer resources to support them.

The first-generation student stories demonstrate a relationship between higher education choices and socio-economic background (Archer et al., 2003). Intention to enter higher education is an intersection between individual and parental expectations. In this study, a family background (parental education, occupational status, and income) was significantly associated with students' initial goal and their academic commitments. Parental expectations regarding their children's university education attainment has an impact on children's aspiration formation (Mistry et al., 2009; Rowan-Kenyon et al., 2008). This resonates with Bui (2002) research that demonstrate that first-generation students often take pride in bringing honour and respect to their families, especially for being first in the family to be awarded a degree.

Students found they are more motivated when they have clear objective. For example this is particularly significant for eight students who knew from early on what they wanted to become in occupational terms. As a result students were clear on which course and university, the entry requirements, qualifications and skills they need to qualify for admission. Students' career directions developed from their personal interests and parental expectations, such as becoming a doctor, lawyer, teacher, chemist or statistician, formed by different intentions, goals and interests, even though no-one in their family was in those profession.

Regardless of their status as first-generation students, they aimed for secure professional jobs with high income and status in society, and this is different with common critiques on first-generation student as less motivated. Optimism with their intellectual ability, along with the impression that educational opportunities are open to every single individual with academic capability, are the keys to success. A clear vision for a future career and high self-efficacy for reaching those goals are two key factors for students' success in academic study.

In addition to above results, students' academic endeavours were also supported by the role played extended family. In this context, older siblings still studying or having graduated from university generated cultural capital for the family. As reported in the findings, their success at university provided help with university education and impacted on how students' viewed education and their desire to continue to a degree course. In another example, extended family members acted as what Crozier and Davies (2006, p. 685) call 'high status role models' for the students. Parents encouraged their child's modelling other individual success within the family. Based on these results, this study find a significance in 'ethnic capital' proposed by Crozier and Davies (2006), Modood (2004), and Shah et al. (2010) in transferring norms and values related to education. This proves the importance of social networks of family and friends that operates as resources to direct transition to university.

The results of the study found the possible influence of the school and its impact on the students' personal, academic and social development. School is the main platform where most of the parents from low to working-class families expect to develop their child's academic capability and to transfer important cultural capital that is limited within their home environment. The role played by the school through teaching and learning process, co-curricular activities, university advice and guidance in the key to motivate them towards university education. Teacher at school have a significant impact on student success. Apart from support and encouragement, obviously the teacher had an adverse effect on some decisions made by students, who noted that advice from the teacher and counsellors had contributed to their decision about universities and courses.

\section{Conclusion}

Taken together, the results of the analysis reveal that first-generation students believed in their intellectual ability and possessed motivation, and that the support system is important to achieve their goals. Even though some studies looks at this separately, these results suggest that the psychological and sociological variables are interrelated and co-founded. This study suggests that student decisions and choices are influenced by individual agency, structural factors, social communities and also mass media. The choices student make are a multifaceted 
process influenced by the quality of information they have about higher education, financial issues and achievement of entry criteria. This group of students has different abilities and was exposed to different experiences. The educational decisions and choices students made reflect autonomous reflection (Archer, 2003). Students aimed for a better life; getting a degree is seen as a process to accumulate capital that can be converted later to occupational gains.

\section{References}

Abdul-Rahim, A. H., \& Azman, N. (2010). Educational Aspirations among First-Generation Students and their Parental Influence towards Pursuing Tertiary Education. Procedia-Social and Behavioral Sciences, 7, 414-418. http://dx.doi.org/10.1016/j.sbspro.2010.10.056

Archer, L., Hutchings, M., \& Ross. A. (2003). Higher Education and Social Class: Issues of Exclusion and Inclusion. London: Routledge Falmer.

Ball, S., Davies, J., David, M., \& Reay, D. (2002). "Classification" and "Judgement": Social Class and the "Cognitive Structures" of Choice of Higher Education. British Journal of Sociology of Education, 23(1), 51-71. http://dx.doi.org/10.1080/01425690120102854

Beal, S. J., \& Crockett, L. J. (2010). “Adolescents' Occupational and Educational Aspirations and Expectations: Links to High School Activities and Adult Educational Attainment". Faculty Publications, Department of Psychology. Paper 491. Retrieved from http://digitalcommons.unl.edu/psychfacpub/491

Becker, G. S. (1962). Investment in Human Capital: A theoretical analysis. Journal of Political Economy (suppl.), str. 9-49.

Benbenishty, R., \& Astor, R. A. (2005). School Violence in Context: Culture, Neighbourhood, Family, School and Gender. New York: Oxford. http://dx.doi.org/10.1093/acprof:oso/9780195157802.001.0001

Benner, A. D., \& Mistry, R. S. (2007). Congruence of Mother and Teacher Educational Expectations and Low-Income Youth's Academic Competence. Journal of Educational Psychology, 99(1), 140-153. http://dx.doi.org/10.1037/0022-0663.99.1.140

Blackstone, T. (2001). Why learn? Higher Education in a Learning Society. Higher Education Quarterly, 55(2), 175-184. http://dx.doi.org/10.1111/1468-2273.00181

Bodovski, K. (2010). Parental Practices and Educational Achievement: Social Class, Race, and Habitus. British Journal of Sociology of Education, 31(2), 139-156. http://dx.doi.org/10.1080/01425690903539024

Bronfenbrenner, U. (2005). Making Human Beings Human: Bioecological Perspectives on Human Development. Thousand Oaks, CA: Sage Publications.

Bui, K. (2002). First-generation College Students at a Four-year University: Background Characteristics, Reasons for Pursuing Higher Education, and First-year Experiences. College Student Journal, 36(1), 3-11.

Cabrera, A. F., Burkum, K., \& Nasa, S. M. (2003). Pathways to a four-year degree: Determinants of degree completion among socioeconomically disadvantaged students. Paper presented at the Association for the Study of Higher Education, Portland, OR.

Ceja, M. (2006). Understanding the Role of Parents and Siblings as Information Sources in the College Choice Process of Chicana Students. Journal of College Student Development, 47(1), 87-104. http://dx.doi.org/10.1080/01425690903539024

Cline, Z., Bissell, J., Hatner, A., \& Katz, M. (2007). Closing the College Readiness Gap. Leadership, 37(2), 30-33.

Conley, D. (2008). Rethinking College Readiness. New England Journal of Higher Education, 22(5), 24-26.

Côté, J. E., \& Levine, C. (1997). Student Motivations, Learning Environments, and Human Capital Acquisition: Toward an Integrated Paradigm of Student Development. Journal of College Student Development, 38(3), 229-243.

Crozier, G., \& Davies, J. (2006). Family Matters: A Discussion of the Bangladeshi and Pakistani Extended Family and Community in Supporting the Children's Education. The Sociological Review, 54(4), 678-695. http://dx.doi.org/10.1111/j.1467-954X.2006.00666.x

Dyke, M., Foskett, N., \& Maringe, F. (2008). Risk and Trust: The Impact of Information and Experience on the Decision to Participate in Post-16 Education. Education, Knowledge and Economy, 2(2), 99-110. http://dx.doi.org/10.1080/17496890802221365 
Engberg, M. E., \& Wolniak, G. C. (2009). Navigating Disparate Pathways to College: Examining The Conditional Effects of Race on Enrolment Decisions. Teachers College Record, 111(9), 2255-2279.

Epstein, J., \& Sheldon, S. (2006). Moving forward: Ideas for research on school, family, and community partnerships. In C. Conrad, \& R. Serlin (Eds.), Handbook for research in education: Engaging ideas and enriching inquiry. California: Sage.

Forsyth, A., \& Furlong, A. (2003). Access to Higher Education and Disadvantaged Young People. British Educational Research Journal, 29(2), 205-225. http://dx.doi.org/10.1080/0141192032000060948

Gibbons, S., \& Vignoles, A. (2009). Access, Choice and Participation in Higher Education. CEE Discussion Papers, CEEDP0101. London School of Economics and Political Science, London, UK. Retrieved August 23, 2009, from http://eprints.lse.ac.uk/23656/1/ceedp101.pdf

Gibson, M. A., Gandara, P., \& Koyama, J. P. (2004). The Role of Peers in the Schooling of U.S. Mexican Youth. In M. A. Gibson, P. Gandara, \& J. P. Koyama (Eds.), School connections: U.S. Mexican Youth, Peers, and School Achievement (pp. 1-17). New York: Teachers College Press.

Goldenberg, C., Gallimore, R., Reese, L., \& Garnier, H. (2001). Cause or effect? A Longitudinal Study of Immigrant Latino Parents' Aspirations and Expectations, and Their Children's School Performance. American Educational Research Journal, 38, 547-582. http://dx.doi.org/10.3102/00028312038003547

Greenbank, P. (2007). Higher education and the Graduate Labour Market: The 'Class Factor'. Tertiary Education and Management, 13(4), 365-376. http://dx.doi.org/10.1080/13583880701546262

Grolnick, W. S., Farkas, M. S., Sohmer, R., Michaels, S., \& Valsiner, J. (2007). Facilitating Motivation in Young Adolescents: Effects of an After-School Program. Journal of Applied Developmental Psychology, 28(4), 332-344. http://dx.doi.org/10.1016/j.appdev.2007.04.004

Harris, K. M., Duncan, G. J., \& Boisjoly, J. (2002). Evaluating the Role of "Nothing to Lose" Attitudes on Risky Behavior in Adolescence. Social Forces, 80(3), 1005-1039. http://dx.doi.org/10.1353/sof.2002.0008

Hossler, D., Schmit, J., \& Vesper, N. (1998). Going to College: How Social, Economic, and Educational Factors Influence the Decisions Students Make. Johns Hopkins: Baltimore.

Inkelas, K. K., Daver, Z. E., Vogt, K. E., \& Leonard, J. B. (2007). Living-Learning Programs and First-Generation College Students' Academic and Social Transition To College. Research in Higher Education, 48(4), 403-432. http://dx.doi.org/10.1007/s11162-006-9031-6

Ituma, A., \& Simpson, R. (2006). The Chameleon Career: An Exploratory Study of the Work Biography of Information Technology Workers in Nigeria. Career Development International, 11(1), 48-65. http://dx.doi.org/10.1108/13620430610642372

James, R., Baldwin, G., \& McInnis, C. (1999). Which University-The factors Influencing the Choice of Prospective Undergraduates. Canberra: Evaluations and Investigations Programme, Higher Education Division, DETYA. http://dx.doi.org/10.1057/9780230114678

Jehangir, R. (2010). Higher Education and First-Generation Students: Cultivating Community, Voice and Place for the New Majority. New York, NY: Palgrave Macmillan.

King, K., Meehan, B., Trim, R., \& Chassin, L. (2006). Marker or Mediator? The Effects of Adolescent Substance Use on Young Adult Educational Attainment. Addiction, 101(12), 1730-1740. http://dx.doi.org/10.1111/j.1360-0443.2006.01507.x

Kirk, C., Lewis-Moss, R., Nilsen, C., \& Colvin, D. (2011). Expectations on Adolescent Educational Aspirations. Educational Studies, 37(1), 89-99. http://dx.doi.org/10.1080/03055691003728965

Laming, M. M. (2010). Stories of Difference: Metropolitan and Rural Students' Attitudes to University. In J. Zadja (Ed.), Globalisation, Ideology and Education Policy Reforms, Globalisation, Comparative Education and Policy Research (pp. 133-152).

Lareau, A. (2003). Unequal Childhoods: Class, Race, and Family Life. Berkeley, CA: University of California Press.

Little, B. R. (2007). Prompt and circumstance: The generative contexts of personal projects analysis. In B. Little, K. Salmela-Aro, \& S. Phillips (Eds.), Personal project pursuit: Goals, actions, and human flourishing (pp. 3-49). Mahwah, NJ: Erlbaum.

Marjoribanks, K. (2005). Family Background, Academic Achievement, and Educational Aspirations as 
Predictors of Australian Young Adults' Educational Attainment. Psychological Reports, 96(3), 751-754. http://dx.doi.org/10.2466/pr0.96.3.751-754

McCarron, G. P., \& Inkelas, K. K. (2006). The Gap between Educational Aspirations and Attainment for First-Generation College Students and the Role of Parental Involvement. Journal of College Student Development, 47(5), 534-549. http://dx.doi.org/10.1353/csd.2006.0059

McMillan, J., \& Western, J. (2000). Measurement of Social-Economic Status of Australian Higher Education Students. Higher Education, 39(2), 223-247. http://dx.doi.org/10.1023/A:1003943824357

Messersmith, E. E., \& Schulenberg, J. E. (2008). When Can we Expect the Unexpected? Predicting Educational Attainment when it Differs from Previous Expectations. Journal of Social Issues, 64(1), 195-211. http://dx.doi.org/10.1111/j.1540-4560.2008.00555.x

Mistry, R. S., White, E. S., Benner, A. D., \& Huynh, V. W. (2009). A Longitudinal Study of the Simultaneous Influence of Mothers' and Teachers' Educational Expectations on Low-Income Youths' Academic Achievement. Journal of Youth and Adolescence, 38(6), 826-838. http://dx.doi.org/10.1007/s10964-008-9300-0

Modood, T. (2004). Capitals, Ethnic Identity and Educational Qualifications. Cultural Trends, 13(2), 87-105. http://dx.doi.org/10.1080/0954896042000267170

Morgan, S. L., \& Aageb, B. S. (1999). Parental Networks, Social Closure, and Mathematics Learning: A Test of Coleman's Social Capital Explanation of School Effects. American Sociological Review, 64, 661-681. http://dx.doi.org/10.2307/2657368

Nurmi, J. E. (2004). Socialization and Self-development: Channelling, Selection, Adjustment, and Reflection. In R. Lerner, \& L. Steinberg (Eds.), Handbook of Adolescent Psychology (2nd ed., pp. 85-124). Hoboken, NJ: Wiley.

Oliverez, P. M., \& Tierney, W. G. (2005). Show us the money: Low-income students, opportunity. Albany, New York: State University of New York Press.

Orthner, D. K., Jones-Sanpei, H., \& Williamson, S. (2004). The Resilience and Strengths of Low-Income Families. Family Relations, 53(2), 159-168. http://dx.doi.org/10.1111/j.0022-2445.2004.00006.x

Ou, S. R., \& Reynolds, A. J. (2008). Predictors of Educational Attainment in the Chicago Longitudinal Study. School Psychology Quarterly, 23(2), 199-229. http://dx.doi.org/10.1037/1045-3830.23.2.199

Pugsley, L., \& Coffey, A. (2002). Keeping the 'Customer' Satisfied: Parents in the Higher Education Marketplace. Welsh Journal of Education, 11(2), 41-58.

Reay, D., David, J. M., \& Ball, S. J. (2001). Choice of Degree or Degrees of Choice? Class, Race and the Higher Education Choice Process. Sociology, 35(4), 855-874.

Roe, C. M. (2005). Negotiating the Freshman Year: Challenges and Strategies among First-Year College Students. Journal of College Student Development, 46(3), 296-316. http://dx.doi.org/10.1353/csd.2005.0022

Rowan-Kenyon, H. T., Bell, A. D., \& Perna, L. W. (2008). Contextual Influences on Parental Involvement in College Going: Variations by Socioeconomic Class. Journal of Higher Education, 79(5), 564-586. http://dx.doi.org/10.1353/jhe.0.0020

Saenz, V. B., Hurtado, D., Barrera, D., Wolf, D., \& Yeung, F. (2007). First in my Family: A Profile of First-Generation College Students at Four Year Institutions Since 1971. Higher Education Research Institute. Retrieved May 7, 2008, from http://www.gseis.ucla.edu/heri/PDFs/resSummary051807FirstGen.pdf

Saunders, P. (2002). Reflections on the Meritocracy Debate in Britain: A Response To Richard Breen and John Goldthorpe. British Journal of Sociology, 53(4), 559-574. http://dx.doi.org/10.1080/0007131022000021489

Schneider, B., \& Stevenson, D. (1999). The Ambitious Generation. Schools and Its Implications. Cardiff: University of Wales Press.

Shah, B. (2007). Being Young, Female and Laotian: Ethnicity as Social Capital at the Intersection of Gender, Generation, Race and Age. Ethnic and Racial Studies, 30(1), 28-50. http://dx.doi.org/10.1080/01419870601006520

Shah, B., Dwyer, C., \& Modood, T. (2011). Explaining Educational Achievement and Career Aspirations among Young British Pakistanis: Mobilizing 'Ethnic Capital'? Sociology, 44(6), 1109-1127. 
http://dx.doi.org/10.1177/0038038510381606

Shulruf, B., Tumen, S., \& Tolley, H. (2008). Extracurricular Activities in School, Do They Matter? Children and Youth Services Review, 30(4), 418-426. http://dx.doi.org/10.1016/j.childyouth.2007.10.012

Sianou-Kyrgiou, E., \& Tsiplakides, I. (2011). Similar Performance, but Different Choices: Social Class and Higher Education Choice in Greece. Studies in Higher Education, 36(1), 89-102. http://dx.doi.org/10.1080/03075070903469606

Simon, J. B., Murphy. J. J., \& Smith, S. M. (2005). Understanding and Fostering Family Resilience. The Family Journal, 13(4), 427-436. http://dx.doi.org/10.1177/1066480705278724

Stewart, E. (2006). Family-And Individual-Level Predictors of Academic Success For African American Students: A Longitudinal Path Analysis Utilizing National Data. Journal of Black Studies, 36(4), 597-621. http://dx.doi.org/10.1177/0021934705276798

Thayer, P. B. (2000). Retaining First Generation and Low Income Students. Opportunity Outlook, 1, 2-8.

Thomas, L., \& Quinn, J. (2006). First Generation Entry into Higher Education: An international Study. Buckingham: Open University Press.

Tierney, W. G., \& Colyar, J. E. (2005). The Role of Peer Groups in College Preparation Programs. In W. G. Tierney, Z. B. Corwin, \& J. E. Colyar (Eds.), Preparing for College: Nine Elements of Effective Outreach (pp. 49-68). Albany, NY: SUNY Press.

Troutman, K. P., \& Dufur, M. J. (2007). From High School Jocks to College Grads: Assessing the Long-Term Effects of School Sports Participation on Females' Educational Attainment. Youth \& Society, 38(4), 443-462. http://dx.doi.org/10.1177/0044118X06290651

Wyer, K. (2005). Today's college freshmen have family income $60 \%$ above national average, UCLA survey reveals. UCLA News. Retrieved May 8, 2008, from http://www.gseis.ucla.edu/heri/PDFs/PR_TRENDS_ 40YR.pdf

Younger, M., \& Warrington, M. (2009). Mentoring and Target-Setting in a Secondary School in England: An Evaluation of Aims and Benefits. Oxford Review of Education, 35(2), 169-185. http://dx.doi.org/10.1080/03054980802666737

\section{Copyrights}

Copyright for this article is retained by the author(s), with first publication rights granted to the journal.

This is an open-access article distributed under the terms and conditions of the Creative Commons Attribution license (http://creativecommons.org/licenses/by/3.0/). 